\title{
PENGEMBANGAN AGROWISATA DESA MULYOSARI \\ DI TENGAH KEHIDUPAN MASYARAKAT MENUJU DESA MANDIRI
}

\section{MULYOSARI VILLAGE AGRO-TOURISM DEVELOPMENT IN THE MIDDLE OF COMMUNITY LIFE TOWARDS INDEPENDENT VILLAGE}

\author{
Andri Wahyudi ${ }^{1}$, Khoirul Yahya ${ }^{2}$ \\ ${ }^{1}$ Fakultas Ilmu Sosial dan Ilmu Politik Universitas Tulungagung, Tulungagung, Indonesia. \\ ${ }^{2}$ Fakultas Ilmu Sosial dan Ilmu Politik Universitas Tulungagung, Tulungagung, Indonesia. \\ andriwahyudi1964@gmail.com \\ khoirulyahya79@gmail.com
}

\begin{abstract}
ABSTRAK
Pengembangan Agrowisata Desa Mulyosari ini dilakukan di kawasan Desa Mulyosari yang berada pada lereng Gunung Wilis Kecamatan Pagerwojo Kabupaten Tulungagung yang mempunyai posisi dan peluang untuk dikembangkannya Agrowisata. Pengembangan Agrowisata diharapkan mampumengembangkan potensi wisatanya meliputi daya tarik, akses menuju kawasan wisata,fasilitas dan kelembagaan dengan baik. Di sisi lain keberadaan Agrowisata Desa Mulyosari diharapkan berdampak positif bagi kehidupan masyarakat desa.

Permasalah dalam penelitian ini adalah bagaimana pengembangan Agrowisata Desa Mulyosari di tengah-tengah kehidupan masyarakat desa. Disamping itu juga berupaya menemukan faktor-faktor apa saja yang mempengaruhinya di kawasan Kecamatan Pagerwojo Kabupaten Tuiungagung.

Tujuan penelitian ini adalah untuk mengetahui, mendeskrepsikan dan mengintepretasikan pengembangan Agrowisata Desa Mulyosari di tengah-tengah kehidupan masyarakat desa. Selain itu juga untuk mengetahui, mesdeskrepsikan dan mengintepretasikan faktor-faktor yang mempengaruhi pengembangan Agrowisata Desa Mulyosari.

Metode penelitian yang dipergunakan dalam penelitian ini adalah menggunakan Analisa Kualitatif. Pengumpulan data melalui teknik wawancara, observasi dan dokumentasi. Sumber data pada penelitian ini yaitu Pemerintah Desa Mulyosari, Dinas Pembangunan Masyarakat Desa, Dinas Pariwisata, Pengelola Agrowisata Desa Mulyosari, pengunjung, masyarakat Desa Mulyosari dan masyarakat sekitar kawanan wisata.

Hasil penelitian pengembangan Agrowisata Desa Mulyosari berhasil meningkatkan ekonomi di tengah tengah masyarakat menuju desa mandiri melalui upaya : pengembangan daya tarik obyek wisata, pengembangan aksesibilitas, pengembangan fasilitas penunjang pariwisata dan pengembangan kelembagaan.
\end{abstract}




\section{Kata Kunci : Pengembangan, Agrowisata Desa Mulyosari, Di Tengah Kehidupan Masyarakat, Menuju Desa Mandiri}

\section{ABSTRACT}

The development of Agrotourism in Mulyosari Village is carried out in the Mulyosari Village area which is located on the slopes of Mount Wilis, Pagerwojo District, Tulungagung Regency which has a position and opportunity for the development of Agrotourism. Agrotourism development is expected to be able to develop its tourism potential including attractiveness, access to tourist areas, facilities and institutions properly. On the other hand, the existence of Agrotourism in Mulyosari Village is expected to have a positive impact on the life of the village community.

The problem in this research is how to develop Agrotourism in Mulyosari Village in the midst of village community life. Besides that, it also seeks to find out what factors influence it in the Pagerwojo District, Tuiungagung Regency.

The purpose of this study was to determine, describe and interpret the development of Agrotourism in Mulyosari Village in the midst of the life of the village community. In addition, to find out, describe and interpret the factors that influence the development of Agrotourism in Mulyosari Village.

The research method used in this research is using qualitative analysis. Data collection through interview, observation and documentation techniques. Sources of data in this study are the Mulyosari Village Government, Village Community Development Office, Tourism Office, Mulyosari Village Agrotourism Manager, visitors, Mulyosari Village community and the community around the tourist herd.

The results of research on the development of Agrotourism in Mulyosari Village have succeeded in increasing the economy in the midst of the community towards an independent village through the following efforts: development of tourist attraction, development of accessibility, development of tourism support facilities and institutional development.

\section{Keywords: Development, Mulyosari Village Agrotourism, In the Middle of Community Life, Towards an Independent Village}

\section{PENDAHULUAN}

Pengembangan agrowisata agar mendapatkan hasil yang optimal harus didukung oleh fasilitas-fasilitas dan Sumber Daya Manusia yang memadai. Fasilitas tersebut dapat berupa akses jalan dan kesediaan kendaraan, penginapan, ataupun pelengkap lain di kawasan wisata. Selain itu, perlu diperhatikan fasilitas kenyamanan dan keamanan agar pengunjung merasa nyaman dan aman saat berwisata. Lokasi agrowisata desa juga harus memperhatikan lingkungan hidup agar area sekitar terjaga dan masyarakat tidak terimbas dampak buruknya. Kabupaten Tulungagung memiliki desa wisata yang berpotensi mengembangkan agrowisata sesuai dengan potensi desa yang berbeda.

Pengembangan agrowisata desa adalah upaya pengelolaan pesona wisata dengan 


\section{PUBLICIANA : JURNAL ILMU SOSIAL DAN ILMU POLITIK \\ VOLUME 14, NO 02 \\ ISSN : 1979 - 0295 / E-ISSN : 2502 - 7336}

optimalisasi panorama alam yang alami, natural, origin dalam kehidupan tradisional di desa (Ridwan \& Aini, 2019) Diantara desa yang memiliki pesona wisata dapat mengundang minat wisatawan di KabupatenTulungagung adalah Agrowisata Mulyosari di Kecamatan Pagerwojo Kabupaten Tulungagung.

Pengembangan Agrowisata Desa Mulyosari dalam bentuk outbound, hidroponik, budidaya anggrek, pengolahan susu dengan andalannya adalah budidaya anggrek. Disana disediakan suatu tempat/kawasan yang mudah diakses yang dimodifikasi sedemikian rupa seperti showroom yang bukan berisi kendaraan bermotor (motor/mobil) melainkan beranekaragam anggrek. Pada tahap awalnya Agrowisata Desa Mulyosari khusus hanya anggrek namun seiring dengan perkembangan waktu mulai muncul dan berkembang juga warung-warung dengan masakan khas daerah setempat,kolam renang, maupun tanaman hidroponik.

Agrowisata adalah sebagai upaya pendidikan nonformal bagi masyarakat setempat sekaligus wisatawan yang melakukan kunjungan wisata (Wijayanti, 2019) Agrowisata memungkinkan terjadinya proses pembelajaran lebih mudah dimengerti dan diiingat. Dan lagi pembelajaran yang berlangsung pada agrowisata sangat dibutuhkan sebab dapat menunjang proses belajar yang dilakukan disekolah untuk mendalami pembelajaran serta berdampak pada peningkatan pemahaman akademik.

Agrowisata dapat memberikan kontribusi positif bagi masyarakat pedesaan. Agrowisata dapat membuka lapangan kerja kepada masyarakat desa sehingga dengan meningkatnya lapangan kerja pendapatan masyarakat akan bertambah yang selanjutnya juga mempengaruhi perekonomian jugaberpengaruh terhadap kehidupan dan kegiatan lain dalam masyarakat.

\section{Rumusan Masalah}

Mengacu pada latar belakang diatas dalam penelitian ini perumusan masalahnya adalah bagaimana pengembangan Agrowisata Desa Mulyosari di tengah kehidupan masyarakat menuju Desa Mandiri. Selain hal tersebut juga berupaya mengungkap faktor pendukung dan penghambatnya.

\section{Tujuan Penelitian}

Adapun yang menjadi tujuan penelitian ini untuk mengetahui, mendeskripsikan dan mengintepretasikan pengembangan Agrowisata Desa Mulyosari di tengah kehidupan masyarakat menuju Desa Mandiri serta untuk mengetahui, mendeskripsikan dan mengintepretasikan faktor pendukung dan faktor penghambatnya di Desa Mulyosari Kecamatan Pagerwojo.

\section{Kegunaan Penelitian}

Penelitian ini dilaksanakan dan berharap beberapa manfaat diantaranya untuk menambah wawasan dan wacana berpikir peneliti terkait Agrowisata dalam hubungannya dengan kehidupan masyarakat desa, untuk memberikan bahan informasi dan kotribusi positif kepada Pemerintah Desa, Pemerintah Kecamatan Pagerwojo, Pemeritah Kabupaten Tulungagung dan Dinas terkait yang memiliki kompetensi dengan pengembangan kepariwisataan pada umumnya serta Agrowisata khususnya. 


\section{KERANGKA TEORI}

\section{Pengertian Pengembangan}

Pengembangan seringkali diilustrasikan sebagai suatu proses, cara, perbuatan untuk mengupayakan adanya peningkatan. Pengembangan juga dapat dinyatakan dan dijelaskan bahwa pengembangan adalah suatu tindakan/perbuatan untuk membuat agar memiliki nilai tambah dari kondisi \& keadaan semula, sehingga menjadi lebih baik/sempurna menyangkut pikiran, pengetahuan dan sebagainya. ((Poerwadarminta, 2014).

Kemudian diambahkan bahwa pengembangan dimaksudkan \& dipergunakan guna validasi dan pengembangan terhadap suatu hasil yang akan ditingkatkan nilainya berdasarkan temuan-temuan melalui penelitian dan percobaan bertitik tolak pada latar belakang dari hasil dimaksud (Setyosari, 2016)

Ada lagi yang berpendapat

pada prinsipnya pengembangan dimaksudkan sebagai langkah baku atau tidak baku/non formal dilakukan dengan sadar, direncanakan, mengarah pada keteraturan, bertanggung jawab, mengenalkan, mengembangkan, membimbing sebagai dasar kepribadian yang proporsional, baku, seiring dengan teknologi, ketrampilan yang sesuai dengan talenta, kemauan \& kapasitas sebagai modal serta inisiasi pribadi guna menaikan, menambah aktualisasi menuju terwijudnya kualitas sumberdaya yang maksimal dari manusia secara individu ((Wiryokusumo, 2014)

Mengacu pada beberapa pernyataan pakar tersebut dimuka bisa dimaknai bahwa pengembangan dimaknai suatu upaya nyata, berencana yang dilakukan secara sadar, terencana dan mengarah guna menjadikan atau memperbaharui sehingga menjadi semakin menambah kegunaan dan mendorong peningkatan kualitas dalam mewujudkan hasil mutu terbaik.

\section{Pengertian Agrowisata}

Agrowisata merupakan pengertian dari istilah bahasa Inggris, Agrotourism . Agro dimaknai pertanian dan tourism dimaknai pariwisata. Agrowisata dapat diartikan melakukan wisata ke lokasi pertanian dalam pengertian yang bebas yang dalam halini meliputi pertanian warga individu, pabrikan, usaha ternak budidaya ikan.

Menurut salah seorang pakar dikatakan

bahwa agrowisata dapat diartikan suatu aktifitas pariwisatayang mempergunakan (pertanian) sebagai sasaran/tempat wisata yang bertujuan menambah wawasan, pengembangan ilmu pengetahuan terkait usaha agraris (Utama \& Suyasa, 2018)

Pernyataan tersebut diatas bisa dimaknai bahwa yang diartikan dengan agrowisata adalah dunia wisata dengan tema pertanian/peternakan dengan tujuan adanya nilai tambah dalam hal pengetahuan, pengalaman, rekreasi dan hubungan usaha dibidang pertanian, perkebunan atau peternakan.

\section{Pengertian Masyarakat Desa}

Menurut Kamus Besar Bahasa Indonesia yang dimaksud masyarakat dimaknai dengan sekelompok orang dengan budaya tertentu serta memiliki pemahaman yang samam. Sedangkan yang dimaksud dengan masyarakat desa ialah masyarakat sebagaiman tersebut diatas yang memiliki pekerjaan pada usaha pertanian, usaha peternakan, usaha perikanan yang keseluruhan tersebut dimana terkait dengan sistem budaya dan sistem sosialnya mewarnai mata pencaharian itu. 


\section{PUBLICIANA : JURNAL ILMU SOSIAL DAN ILMU POLITIK \\ VOLUME 14, NO 02 \\ ISSN : 1979 - 0295 / E-ISSN : 2502 - 7336}

Selanjutnya ada yang mengatakan bahwa masyarakat desa adalah suatu masyarakat yang ditandai dengan ciri-ciri beberapa diantaranya adalah : adanya hubungan, ikatan sikap perlaku yang spesifik pada semua elemen kehidupan yang bersifat baku, berkelanjutan memunculkan tanda-tanda kusus dari kelompok, dimana manusia secara perorangan tergabung dalam kelompok/masyarakat (Syani, 2015).

Mengacu pada pendapat pakar tersebut diatas dapat dimaknai bahwa masyarakat adalah tempat individu-individu hidup bersama menghasilkan peradaban/budaya tertentu. Dampak yang timbul dengan adanya pengembangan agrowisata, berdampak langsung maupun berdampak pada saat nantinya serta berdampak induksi. Dampak tidak langsung dan dampak induksi termasuk damapk sekunder, sedangkan dampak tidak langsung merupakan dampak primer.

\section{METODE PENELITIAN}

Metode penelitian dimaksudkan sebagai cara ilmiah guna mendapatkan data/informasi bertujuan dan memiliki kegunaan tertentu.

Kemudian ada yang mengatakan sebagai penelitian yang baik jika penelitiaan itu menghasilkan suatu rangkuman melalui tahapan/langkah yang sitematis dalam menggunakan pembuktian secara menyakinkan (Sugiono, 2016)

\section{Pendekatan Penelitian}

Dalam penelitian ini menggunakan pendekatan penelitian kualitatif. Pemakaian pendekata penelitian ini dipakai sebab peneliti berharap dapat menggambarkan secara lebih dalam terkait pengembangan agrowisata ditengah-tengah kehidupan masyarakat Desa Mulyosari Kecamatan Pagerwojo Kabupaten Tulungagung.

Selain itu ada yang mengatakan maksud penelitian kualitatif yakni penelitian yang berusaha untuk mencari \& berusaha untuk memperoleh informasi yang mendalam terkait permasalahan yang diteliti dari pada banyaknya informasi dari obyek studi (Ghoni, 2014)).

Selanjutnya metode penelitian yang dipilih dalam pendekatan kualitatif adalah metodologi kualitatif sekaligus membentuk \& memilih metode dalam penelitian ini. Secara umum berdasarkan pendapat pakar tersebut diatas penelitian kualitatif umumnya dipergunakan dalam ilmu-ilmu sosial berkaitan dengan perilaku manusia, yang terkandung makna dan sulit diukur secara kuantitatif/angka-angka. Untuk itu perlu pemahaman (understanding) terhadap arti yang diilustrasikan sebagai pola tingkah laku warga sesuai penafsiran warga masyarakat itu sendiri.

\section{Fokus Penelitian}

Walaupun penelitian ini memakai pendekatan kualitatif, dalam penelitian ini tetap dibutuhkan fokus penelitian agar obyek studi atau obyek penelitian tidak meluas.

Selanjutanya fokus penelitian dalam penelitian ini adalah :

1. Pengembangan Agrowisata Desa Mulyosari di tengah kehidupan masyarakat menuju Desa Mandiri.
a. Kondisi masyarakat
b. Potensi alam
c. Langkah langkah yang ditempuh

2. Faktor yang mendorong dan faktor penghambat pengembangan Agrowisata Desa

Mulyosari di tengah kehidupan masyarakat menuju Desa Mandiri.

a. Faktor pendorong :

1). Sumberdaya Manusia 
2). Pemerintahan Desa/Pemerintah Kabupaten

3) Potensi Alam

b.Faktor yang menghambat :

1). Modal

2). Infrastruktur

3). Promosi

\section{Lokasi Penelitian}

Karena kebetulan peneliti adalah putra daerah dan berdomisili dekat dengan obyek studi, hal ini menjadikan pendorong peneliti untuk mendalami serta ingin mengetahui lebih jauh terkait pengembangan Agrowisata Desa Mulyosari di Kecamatan Pagerwojo Kabupaten Tulungagung.

Salah seorang pakar mengatakan bahwa cara terbaik yang dapat dilalui oleh peneliti untuk menemtukan kesesuaian lokasi penelitian adalah yakni peneliti menuju obyek studi guna melakukan suatu observasi terhadap gejala/kejadian secara wajar (Moleong, 2021).

Lokasi penelitian adalah di kawasan Agrowisata Desa Mulyosari Kecamatan Pagerwojo Kabupaten Tulungagung. Pemilihan terhadap lokasi tersebut berdasarkan atas beberapa pertimbangan diantaranya adalah efisiensi \& keterjangkauan dalam obyek studi/penelitian, kemudahan dalam mendapatkan data-data yang diperlukan disamping itu juga untuk menambah pengetahuan serta wawasan peneliti.

\section{Jenis dan Sumber Data}

Data adalah bagian teramat penting dalam penelitian, oleh sebab itu itu validitas, kelengkapan dan kebenaran data sangat mempengaruhi hasil akir penelitian ini.

\section{Jenis Data}

\section{a. Data primer}

Data yang diperoleh langsung dari sumber informasi di lokasi penelitian atau objek penelitian dengan cara mengumpulkan data-data yang berguna dan permasalahan yang diangkat. Dalam hal ini data diperoleh secara langsung dari sumber pertama dilapangan yang meliputi data yang diberikan oleh narasumber/informan.

\section{b. Data Sekunder}

Data yang diolah, dipublikasikan oleh orang lain atau lembaga lain. Sumber data sekunder berasal dari buku buku, program kerja, agenda/kegiatan, laporan, literatureliteratur yang terkait.

\section{Sumber Data}

Yang menjadi sumber data yang akan dipakai penulis diantaranya :

\section{a. Sumber Data Primer}

Informan atau narasumber dalam penelitian ini adalah :
1) Kepala Desa
2) Pengelola kawasan
3) Masyarakat Desa Mulyosari
4) Pengunjung

\section{b. Sumber Data Skunder}

Yang menjadi sumber data primer diantaranya adalah:

1) Buku-buku terkait agrowisata

2) Kegiatan/agenda

3) Jurnal/majalah

4) Laporan/Hasil penelitian 


\section{Instrumen Penelitian}

Yang dimaksud Instrumen penelitian dalam penelitian ini adalah peralatan yang dipakai untuk mendapatkan, memperoleh, mengolah data dalam rangka mencari solusi dalam penelitian ini.

Selanjutnya dapat dikatakan bahwa instrumen yang dipergunakan untuk penelitian diantaranya peneliti sendiri, metode/pedoman wawancara ,metode/panduan observasi, buku catatan, alat dokumentasi dll (Sangadji, 2016).

Mengacu pada pendapat tersebut diatas diasumsikan bahwa dalam suatu penelitian selalu dilaksanakan observasi, wawancara, buku catatan diperlukan juga dalam proses wawancara, dokumentasi dilakukan ditunjang dengan beberapa buku yang berkaitan dengan permasalahan yang ditelaah/dibahas.

Dalam penelitian ini instrumen penelitian yang dipakai diantaranya sebagai berikut:

\section{Peneliti Sendiri}

Yaitu peneliti sendiri sebagai peneliti juga merupakan alat untuk melakukan suatu penelitian

\section{Panduan Wawancara}

Berupa daftar pertanyaan yang akan diajukan kepada informan dalam penelitian ini. Wawancara ini dibagi menjadi 2 (dua) golongan yaitu wawancara dan wawancara tak berencana.

\section{Buku Catatan}

Berupa perlengkapan alat tulis menulis dipergunakan menulis/mencatat segala informasi yang berkaitan dengan pengembangan agrowisata di Desa Mulyosari Kecamatan Pagerwojo Kabupaten Tulungagung.

\section{Teknik Pengumpulan Data}

Teknik pengumpulan data yang dipergunakan dalam penelitian ini diantaranya adalah sebagai berikut :

1. Teknik Observasi (Pengamatan)

Teknik ini dipergunakan guna mendapatkan data yang lebih akurat berkaitan dengan pengembangan agrowisata Desa Mulyosari di tengah kehidupan masyarakat menuju Desa Mandiri dalam wilayah Kecamatan Pagerwojo Kabupaten Tulungagung.

2. Teknik Wawancara

Wawancara adalah teknik pengumpulan data dengan melakukan wawancara atau interviue secara langsung dengan informan/narasumber, pihak-pihak yang berkaitan dengan pokok permasalahan..

3. Metode Dokumentasi

Adalah teknik untuk mengumpulkan data dengan cara mengumpulkan informasi yang berupa buku-buku, dokumen atau bahan pustaka lain yang ada hubunganya dengan permasalahan yakni pengembangan agrowisata Desa Mulyosari di tengah kehidupan masyarakat menuju Desa Mandiri, untuk menunjang kelengkapan data-data terkait obyek penelitian.

\section{Teknik Analisa Data}

Dalam penelitian ini analisis data dilakukan seperti pendapat Milles \& Huberman yakni ada 4 tahapan diantaranya pemilihan data, display data, verifikasi data dan penarikan 
kesimpulan.

\section{Pemilihan Data}

Data yang didapatkan dilapangan dalam bentuk narasi dirinci, lalu dilakukan proses reduksi sesuai tema atau pola yang dikehendaki.. Ini dijalankan secara kontinyu dalam waktu selama penelitian. Validitas data tercapai apabila proses reduksi data berlangsung beberapa kali.

\section{Display Data}

Penyusunan dan penyajian data sehingga bentuknya menjadi mudah dimengerti \& dipahami, sehingga peneliti dapat memberikan gambaran secara menyeluruh dari penelitian ini. Selanjutnya data disusun dalam bentuk tabel, gambar atau grafik.

\section{Menarik Kesimpulan dan Verifikasi}

Kesimpulan \& diverifikasi secara terus- menerus selama penelitian berlangsung sehingga diperoleh kesimpulan bersifat "grounded".

Analisa data dilaksanakan secara berkelanjutan, berulang-kali dan terus-menerus. Masalah reduksi data, penyajian data,dan penarikan kesimpulan/verifikasi menjadi gambaran keberhasilan secara berurutan sebagai rangkaian kegiatan analisis yang saling susul menyusul.

Untuk memberikan pemahaman yang lebih jelas tentang model interaktif, dengan komponen-komponennya mencakup komponen komponen analisis ( reduksi, penyajian data,penarikan kesimpulan/verifikasi ) ditambah dengan pengumpulan data, Miles \& Hubermen dalam Sugiyono (2013:247) mendeskripsikannya melalui gambar beriku:

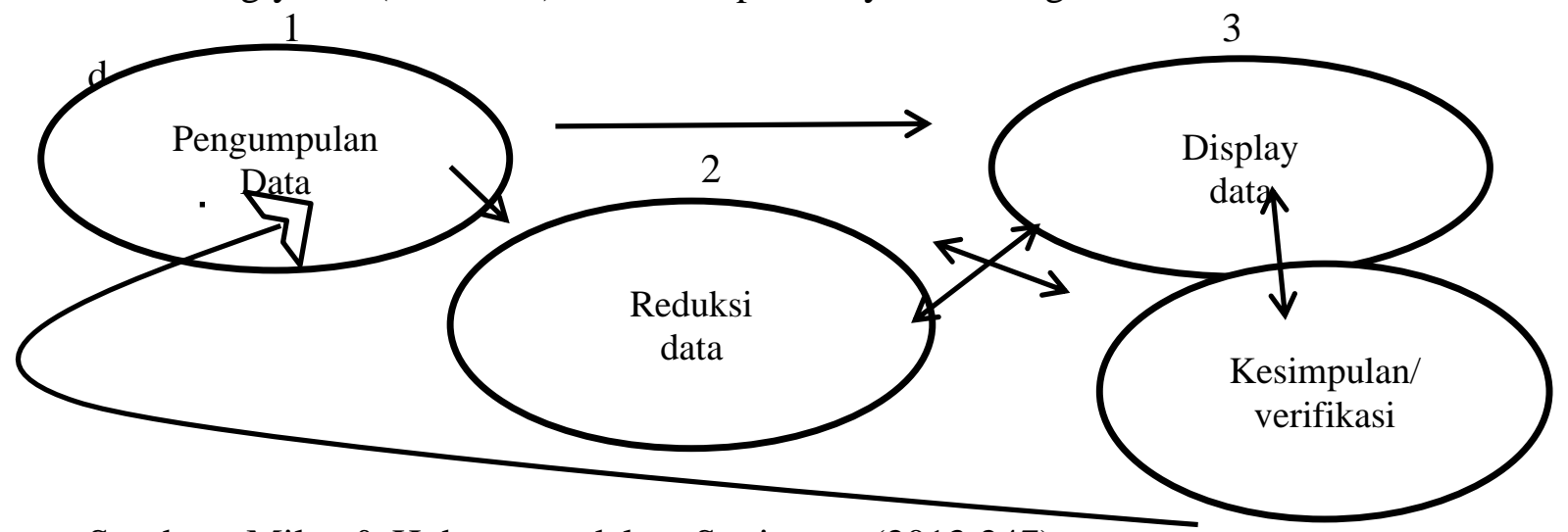

Sumber : Miles \& Hubermen, dalam Sugiyono (2013:247)

Gambar 1

Komponen-komponen Analisa Data Model Interaktif

\section{Keabsahan Data}

Pada penelitian kualitatif berlaku standar dalam melihat tingkat kepercayaan/ keberhasilan suatu penelitian. Karenanya data-data yang terkumpul harus bisa dipertanggungjawabkan.

Pendapat pakar mengatakan terdapat 4 kriteria yang dianjurkan untuk dalam tehnik melihat keabsahan data. Adapun 4 kriteria dimaksud adalah : tingkat kepercayaan (credibility), tingkat keteralihan (transferability), tingkat ketergantungan (dependability), dan kepastian (konfirmobility) (Prastowo, 2011).

Trianggulasi merupakan langkah terlazim guna menjamin validitas data dalam penelitian kualitatif. Trianggulasi merupakan upaya pemeriksaan keabsahan data dengan memanfaatkan hal-hal yang lain selain data tersebut guna pengecekan data atau sebagai pembanding terhadap data terkait. 


\section{PUBLICIANA : JURNAL ILMU SOSIAL DAN ILMU POLITIK \\ VOLUME 14, NO 02 \\ ISSN : 1979 - 0295 / E-ISSN : 2502 - 7336}

\section{HASIL DAN PEMBAHASAN}

Desa Mulyosari merupakan salah satu Desa yang ada dalam wilayah Kecamatan Pagerwojo Kabupaten Tulungagung, berada pada lereng Gunung Wilis berketinggian $240 \mathrm{~m}$ di atas permukaan air laut.

Warga desa Mulyosari cukup beraneka ragam. Berlatar belakang pekerjaan petani, buruh, ASN, pedagang, dan usaha lain. Desa Mulyosari mengembangkan agrowisata berbasis masyarakat meliputi budidaya anggrek. Beberapa bidang pekerjaan lain yang terkait berharap dapat menampung tenaga kerja dan tentu saja sebagai salah satu upaya meeningkatkan kemandirian masyarakat Desa Mulyosari.

Pengembangan Agrowisata Desa Mulyosari di tengah kehidupan masyarakat desa dapat berhasil dan pelaksanaan pembangunan di Desa Mulyosari juga dapat berlangsung, hal ini adalah bukti adanya kemandirian yang tentu saja juga adanya peningkatan kesejahteraan \& taraf hidup warga Desa Mulyosari \& masyarakat sekitar kawasan wisata.

Adanya hal tersebut menjadikan Desa Mulyosari mempunyai kapasitas dalam proses planning, organizing, actuating sekaligus controling dalam pembangunanpedesaan menuju kemandirian desa.

\section{Faktor Pendukung}

\section{Potensi \& Lingkungan Alam}

Dalam mengembangkan Agrowisata sebelumnya harus mengetahui potensi yang ada di daerah/kawasan obyek wisata serta lingkungan alamnya. Semakin positip dukungan dari potensi \& lingkungan alamnya terhadap upaya pengembangan diawali misalnya dengan mengetahui potensi/kondisi tanah \& lahan serta jenis tanaman apa yang cocok untuk dibudidayakan serta dikembangkan. Perlu diketahui bahwa selain potensi tanah, lingkungan alam juga sangat menetukan keberhasilan pengembangan Agrowisata. Lingkungan alam yang menunjukkan keaslian, keunikan, kenyamanan, serta keindahannya merupakan asset yang begitu penting serta mendukung industri wisata dengan pesonanya dapat dibaratkan potensi \& lingkungan alam sebagai magnet yang dapat mendatangkan wisatawan untuk berkunjung ketempat-tempat wisata seperti kawasan Agrowisata Desa Mulyosari. Namun begitu satu hal yang perlu diingat kegiatan wisata diharapkan tidak merusak/mencemari alam sebab pada umumnya tujuan dari pengembangan agrowisata adalah untuk mengagumi, menikmati keindahan flora \& fauna, hewan di lingkungan alaminya serta sebagai salah satu sarana edukasi.

\section{Semangat Kewirausahaan Masyarakat}

Semangat kewirausahaan/berwirausaha dimaksudkan sebagai suatu upaya masyarakat untuk mempadukan kepribadian, keuangan dan sumberdaya manusia. Oleh sebab itu semangat kewirausahaan yang ada pada rata-rata warga masyarakat Desa Mulyosari dapat dimaknai sebagai suatu pekerjaan atau karier yang harus bersifat fleksibel dan imajinatif, mampu merencanakan dan mengambil resiko keputusan dan tindakan untuk mencapai tujuan yang diinginkan. Warga masyarakat Desa Mulyosari yang memiliki karakter/semangat kewirausahaan seperti pekerja keras, inisiatif dalam penentuan tujuan \&sasaran, ulet, percaya diri, kemauan untuk menerima ide-ide baru, berusaha mencari informasi dan berusaha untuk terus belajar, selalu mencari peluang untuk selalu mendukung adanya perubahan yang lebih baik. Semua yang telah tersebut diatas sebagian terbesar ada pada rata-rata warga masyarakat Desa Mulyosari dan itu semua sangat mendukung pengembangan Agrowisata Desa 
Mulyosari.

\section{Keberfihakan Pemerintah}

Upaya keberfihakan yang dilakukan pemerintah terhadap pengembangan Agrowisata Desa Mulyosari dalam hal ini diantaranya adalah berupa inisiasi Pemerintah Kabupaten Tulungagungn untuk pengajuan anggaran pembangunan akses jalan menuju ke kawasan Agrowisata Desa Mulyosari bahkan sampai sebanyak 3 kali pengajuan, sehingga masyarakat yang berminat menuju kawasan menjadi lebih mudah menjangkau apabila dibandingkan sebelum dibangunnya sarana prasarana jalan tersebut. Satu lagi bentuk keberfihakan pemerintah dalam hal ini Dinas Pariwisata Pemerintah Kabupaten Tulungagung yakni getolnya melakukan sosialisasi/promosi tentang pengembangan Agrowisata Desa Mulyosari walaupun hingga saat ini belum ada bentuk sosialisasi/promosi yang baku.

\section{Faktor Penghambat}

\section{Belum ada Program Pemasaran/Promosi Pariwisata}

Betapapun berkualitasnya suatu produk, betapapun indahnya Agrowisata Desa Mulyosari, jika konsumen belum pernah melihat/mendengarnya tidak yakin produk/Agrowisata Desa Mulyosari akan bermanfaat baginya, maka wisatawan tidak akan pernah membelinya. Karenanya jika pemasaran/upaya pengenalan agrowisata belum ada pola yang jelas seperti model pemasaran, usaha penyebaran promosi wisata, upaya persuasif \& mengarahkan konsumen hal ini tentu akan menghambat upaya pengembangan Agrowisata Desa Mulyosari di tengah-tengah kehidupan masyarakat desa.

\section{Minimnya Koordinasi}

Hal ini terjadi sebagai akibat bentuk kerjasama yang dilakukan dan dijalin oleh fihakfihak yang sama-sama mengupayakan pengembangan terhadap Agrowisata Desa Mulyosasi belum terkoordinir secara terpadu dan justru terjadi over laping/tumpang tindih yang dipicu ego sektoral masing-masing fihak. Selain itu pengelola Agrowisata Desa Mulyosari juga masih kurang koordinasi dalam bekerjasama secara menyeluruh karena selama ini koordinasi/kerjasama yang dilakukan hanya melibatkan 2 belah fihak walaupun sebenarnya yang berkepentingan dengan pariwisata itu banyak fihak. Hal ini sebenarnya dan seharusnya secara keseluruhan yang terkait dengan Agrowisata Desa Mulyosari duduk bareng berkoordinasi secara terpadu sehingga tidak terjadi overlap antar Dinas Pemerintah (Dinas Pariwisata-Dinas Pembangunan Masyarakat Desa, Perbankan, Pemerintah Desa), fihak swasta, pengusaha Hotel, transport, UMKM dan fihak-fihak yang memiliki ketertarikan terhadap pengembangan Agrowisata.

\section{Kurangnya SDM yang Profesional}

Berdasarkan paparan di depan dapat dijelaskan bahwa SDM yang professional merupakan faktor kunci keberhasilan dalam mewujudkan pengembangan Agrowisata di suatu kawasan tertentu. SDM yang professional juga sebagai motor penggerak industri pariwisata dan penentu daya saing industri pariwisata. Sesuai realita di obyek studi dapat dikemukakan bahwa masih terjadi kekurangan tenaga/SDM yang professional dalam penanganan pengembangan Agrowisata Desa Mulyosari dan apabila ini dibiarkan begitu saja tanpa ada langkah-langkah terobosan untuk meningkatkan mutu, kinerja suberdaya manusia yang terlibat dalam agrowisata Desa Mulyosari, hal ini dapat menghambat upaya pengembangan yang diinginkan. Langkah-langkah untuk menutupi kekurangan tenaga SDM yang Profesional bisa ditempuh misalnya dengan pendidikan pariwisata, pelatihan pemandu wisata yang secara 


\section{PUBLICIANA : JURNAL ILMU SOSIAL DAN ILMU POLITIK \\ VOLUME 14, NO 02 \\ ISSN : 1979 - 0295 / E-ISSN : 2502 - 7336}

umum harus dimiliki oleh masyarakat tidak saja yang berada dalam internal pengelola Agrowisata Desa Mulyosari, juga harus dimiliki oleh masyarakat sekitar kawasan wisata yang pada ujungnya nanti penghasilan meningkat serta kesejahteraan masyarakatpun menjadi semakin baik.

\section{KESIMPULAN}

Pengembangan Agrowisata Desa Mulyosari Di Tengah Kehidupan Masyarakat Menuju Desa Mandiri berhasil dengan baik dengan mengupayakan kemandirian masyarakat Desa Mulayosari melalui beberapa langkah pengembangan diantaranya adalah sebagai berikut :

a. Peningkatan Pesona obyek dunia wisata (Attraction)

Peningkatan pesona dunia wisata di Agrowisata Desa Mulyosari lebih condong ke wisata edukasi. Di dalam kawasan Agrowisata Desa Mulyosari ada arena bermain, usaha pertanian dengan media, budidaya anggrek, dan lain-lain.. Bagi wisatawan budidaya anggrek. di sekitar kawasan Agrowisata Desa Mulyosari banyak terdapat showroom anggrek, kemudian dari kios-kios tempat memajang anggrek berkembang menjadi warung/wisata kuliner. Agrowisata Desa Mulyosari adalah budidaya anggrek, merangsang munculnya wisata lainnya diseputaran kawasan wisata bahkan area perkemahan juga ada.

b. Pengembangan Aksesibilitas (Accessibility)

Hal ini dilakukan melalui penyiapan layanan antar jemput wisatawan. Sebenarnya juga kawasan ini cukup strategis yakni di jalur angkutan umum, berdekatan juga sama fasilitas kesehatan. Bagi wisatawan dari luar kota/relatif jauh dari kawasan wisata yang menuju Agrowisata Desa Mulyosari disiapkan paket wisata olehpihak pengelola wisata. Jasa antar jemput difasilitasi oleh pengusaha transport berharap dapat meningkatkan perekonomian Desa Mulyosari kususnya maupun masyarakat desa-desa sekitar kawasan wisata.

c. Pengembangan Fasilitas (Amenitas)

Agrowisaqta Desa Mulyosari ada area untuk istirahat seperti homestay untuk groub/kelompok, area perkemahan. Agrowisata Desa Mulyosari juga menyediakan alat kelengkapan P3K untuk masyarakat atau warga.

d. Pengembangan Kelembagaan

Agrowisata Desa Mulyosari melibatkan berbagai dinas utamanya DPMD, dinas pariwisata dan beberapa kelembagaan yang ada di desa diantaranya BPD, PKK.. BPD dalam upaya pengembangan kelembagaan. Disamping itu juga melakukan kemitraan dengan fihak perbangkan BNI guna layanan perbankan, kemudian juga kerjasama dengan pelaku wisata. Agrowisata di tengah-tengah kehidupan masyarakat mampu meningkatkan ekonomi masyarakat Desa Mulyosari dan masyarakat sekitar kawasan wisata.

Dampak Pengembangan Agrowisata di tengah-tengah kehidupan masyarakat Desa Mulyosari Kecamatan Pagerwojo Kabupaten Tulungagung adalah terbukanya lapangan \& kesempata kerja baru, perekonomian masyarakat menjadi semakin baik, pendapatan asli daerah meningkat, pembangunan dapat berjalan sesuai dengan harapan masyarakat. 
Adapun faktor-faktor yang berpengaruh terhadap pengembangan Agrowisata di tengah-tengah kehidupan masyarakat Desa Mulyosari Kecamatan Pagerwojo Kabupaten Tulungagung adalah :

a. Faktor Pendukung :

- Potensi \& Lingkungan Alam

- Semangat Kewirausahaan Masyarakat

- Keberfihakaan Pemerinatah

b. Faktor Penghambat :

- Belum Adanya Program Pemasaran/Promosi Pariwisata

- Minimnya Koordinasi

- Kurangnya SDM yang profesional

\section{B. Masukan}

Masukan yang diingikan diantaranya :

1. Sebagai salah satu bukti keberfihakan Pemerintah dalam mengupayakan dorongan cukup intensip pada Agrowisatadengan memprioritaskan sarana \& prasarana yang sangat diperlukan.

2. Perlu lebih ditingkatkan lagi langkah-langkah koordinasi beberapa fihak yang terkait dengan pengembangan Agrowisata sehingga dapat dikurangi adanya saling tumpang tindih terkait siapa yang harus menangani dan siapa pula yang harus bertanggung jawab terkait program/kebijakan pengembangan agrowisata.

3. Lebih diberikan kesempatan diadakannya pendidikan, latihan, bimbingan terkait pengembangan Agrowisata sehingga tenaga profesional di bidang Agrowisata pelen-pelan akan segera tercukupi.

\section{DAFTAR PUSTAKA}

Ghoni, H. M. (2014). Djunaidi, \& Fauzan Al-Mansur. Filsafat Ilmu Dan Metode Penelitian. Moleong, L. J. (2021). Metodologi penelitian kualitatif. PT Remaja Rosdakarya.

Poerwadarminta, W. J. S. (2014). Kamus bahasa Indonesia lengkap, Jakarta: PT. Balai Pustaka.

Prastowo, A. (2011). Metode penelitian kualitatif dalam perspektif rancangan penelitian. Jogjakarta: Ar-Ruzz Media.

Ridwan, M., \& Aini, W. (2019). Perencanaan Pengembangan Daerah Tujuan Pariwisata. Deepublish.

Sangadji, E. M. (2016). Sopiah. 2013. Perilaku Konsumen, 8.

Setyosari, H. P. (2016). Metode penelitian pendidikan \& pengembangan. Prenada Media. Sugiono, S. (2016). Metode penelitian kuantitatif, kualitatif, dan r \& d. Bandung: Alfabeta. Syani, A. (2015). Kearifan Lokal sebagai Aset Budaya Bangsa dan Implementasinya dalam Kehidupan Masyarakat. Socius+Logos (17 April 2013), Http://Staff. Unila. Ac. Id/Abdulsyani/2013/04/17/Kearifan-Lokal-Sebagai-Aset-Budaya-Bangsa-DanImplementasinya-Dalam-Kehidupan-Masyarakat/Diakses, 7.

Utama, I. G. B. R., \& Suyasa, N. L. C. P. S. (2018). The Segmentation of Visitor World Heritage Tourist Attraction of Jatiluwih Bali. Cultivating The Spirit of Sustainability, Innovation, \& Governance For Businesses Around The World, 44.

Wijayanti, A. (2019). Strategi Pengembangan Pariwisata Edukasi di Kota Yogyakarta. Deepublish. 
PUBLICIANA : JURNAL ILMU SOSIAL DAN ILMU POLITIK

VOLUME 14, NO 02

ISSN : 1979 - 0295 / E-ISSN : $2502-7336$

Wiryokusumo, I. (2014). KI HAJAR DEWANTARA, MENGURANGI PENGARUH BARAT SECARA KULTURAL. Jurnal Budaya Nusantara, 1(2), 121-125. 